\title{
The Reform Process of Mongolian Higher Education and Its Further Tendency
}

\author{
Ulziikhuyag Baasanjav', Baljinnyam Gungaa², Enkhchimeg Dolgorsuren,"* \\ ${ }^{1}$ Deputy Director for Research and Social Partnership, National Defense University of Mongolia, Mongolia \\ ${ }^{2}$ Faculty Development Center, National Defense University of Mongolia, Mongolia \\ ${ }^{3}$ Department of Economics and Management, Institute of Security, National Defense University of Mongolia, Mongolia
}

Received December 23, 2020; Revised February 23, 2021; Accepted March 23, 2021

\section{Cite This Paper in the following Citation Styles}

(a): [1] Ulziikhuyag Baasanjav, Baljinnyam Gungaa, Enkhchimeg Dolgorsuren, "The Reform Process of Mongolian Higher Education and Its Further Tendency," Universal Journal of Educational Research, Vol. 9, No. 5, pp. 1055-1063, 2021. DOI: 10.13189/ujer.2021.090518.

(b): Ulziikhuyag Baasanjav, Baljinnyam Gungaa, Enkhchimeg Dolgorsuren (2021). The Reform Process of Mongolian Higher Education and Its Further Tendency. Universal Journal of Educational Research, 9(5), 1055-1063. DOI: 10.13189/ujer.2021.090518.

Copyright $\mathrm{C} 2021$ by authors, all rights reserved. Authors agree that this article remains permanently open access under the terms of the Creative Commons Attribution License 4.0 International License

\begin{abstract}
Since the 1990s, the significant modifications and innovations have been made in Mongolian higher education system. The policy that Mongolian States prioritize towards higher education is to improve the legal environment, adjust higher education institutions to international standards as well as develop world-wide competitive specialists. Higher education institutions have paid great attention to building a result-based education system, developing research-based universities, improving higher education quality and increasing the employment opportunities of graduates. Moreover, in order to prepare high-qualified, skillful specialists, the issue of improving the quality of education programs is considered to be the most essential. The major goal of Mongolian higher education innovation is to develop research-based universities with internationally approved education programs. Mongolian development policy of higher education related to "Global sustainable development policy", "Education 2030-Incheon Declaration", "Vision 2050-Mongolian long term development policy", "State policy on education" is striving to build a knowledge-based society, accelerate economic development, improve people's lives, create productive structure which could provide social equality. With the frame of higher education reform in Mongolia, it is vital to create a qualified higher education structure with equal access, and also to increase the number of graduates who are sensitive to labor market demand as well as competitive in the world.
\end{abstract}

Keywords Higher Education, Higher Education Reform, Quality Education, Curriculum, Quality Assurance

\section{Introduction}

It is stated in the United Nations "Universal Declaration of Human Rights" (1948) that "Everyone has equal right to access to higher education according to their talents.[1] Also in "Recommendation concerning the Status of Higher-Education Teaching Personnel" (1997) determined that higher education is a post-secondary education training, course, research programs provided by State institutions, accredited universities or other higher education institutions.[2] Having founded in 1942, National University [3] of Mongolia became the main fundament of Mongolian higher education institutions to be set up. It was the 1990s when Mongolian Higher Education system's reform started and in the frame of the reform the following issues were tackled:

1. Mongolian higher education reform gave the opportunity to decentralize the congestion of governance at all levels.

2. Created conditions to democratize governance and created an environment for higher education institutions to be independent. 
3. Created legal basis to establish private institutions.

4. It was considered that one of the financial sources of State higher education institutions should be tuition fees, consequently, the legal environment for it was created.

5. It was legalized that State Higher Education institutions would be led by directors based on choice.

In 1995, "The first law of Higher Education" was passed and higher education system transformed from Russian model to a brand new American system. "Recommendation concerning the Status of Higher-Education Teaching Personnel" states that "Higher education institutions are accredited states and private institutions related to universities, institutions, other educational institutions, educational structural branches as well as research and cultural centers [4]. Nowadays, there are 88 higher education institutions and 7143 faculties.

Mongolian State is striving to create a complex system that gives students the opportunity to acquire essential skills to work productively and live stable and beautiful lives as well as develop the right attitudes, so reform in higher education system [5] is being made intensively. In terms of our country, the most essential issue is to improve the quality of higher education by learning other county's experience and domesticating it to Mongolian circumstances.

The purpose of this study is to determine the process and trend of reforming the higher education system in Mongolia, its key indicators. To achieve the goal of the study, the following tasks were set for them:

1. Historical development, change in the policy and direction of development of higher education.

2. Current state of higher education reform.

3. Analysis of the main indicators of higher education and factors influencing on it

4. Changes and tendencies in higher education.

An attempt was made to integrate and explain the process of changing and reforming Mongolia's higher education system at the macro level. Today, higher education institutions in our country are beginning to pay more attention to the introduction and development of results-oriented education systems, the development of research universities, improving the quality of higher education, and increasing the employment of graduates. This reflects the process of reform of the higher education system.

\section{Methodology}

Classical linear regression analysis is used to determine the regularity and relationship between the numerical values of any industry. On the other hand, correlation analysis is a method used to assess the strength of interaction between these parameters. Regression and correlation analysis are inextricably linked and mutually dependent. There are many different regression methods and form of evaluation, depending on the nature of the data used in the study. It is important to choose the most appropriate evaluation methods to obtain a high-precision result with a low error rate. This study used a multidimensional regression model and exponential dynamic analysis, an extended form of a simple linear regression model.

The purpose of this study is to study and show the relationship between trends in key indicators of higher education and the impact of key social, economic, and domestic factors on changes in the total number of students. Socio-economic factors include GDP (in constant 2010 prices), the number of universities and colleges, and average tuition fees, while the main household indicators include the average monthly household income. Trends in key indicators of higher education are calculated dynamically, and factor analysis of impact is based on data for 2001-2019 using the method of assessing multifactorial regression.

Table 1. Explanation of modeling equations

\begin{tabular}{|c|c|}
\hline Model & The multidimensional linear regression model \\
\hline \multirow[b]{2}{*}{ Variables } & $\begin{array}{l}\text { The related variables }\left(\mathrm{Y}_{\mathrm{t}}\right) \text { : The corresponding variable number of students at higher education institutions } \\
\text {-SER01 }\end{array}$ \\
\hline & $\begin{array}{c}\text { Interpreting variable: } \\
\text { Average monthly income of one family, Mongolian national tugrug- SER04 } \\
\text { Average tuition fee, thousand- SER05 } \\
\text { GDP at constant 2010 prices- SER06 } \\
\text { The number of the main teachers of higher education institutions is their- SER07 } \\
\text { Number of universities and colleges- SER08 }\end{array}$ \\
\hline Hypothesis & $\begin{array}{c}H_{0}: \beta_{1}=\beta_{1}=\beta_{2}=\beta_{3}=\beta_{4}=\beta_{5}=0 \\
H_{1}: \beta_{1} \neq 0, \beta_{2} \neq 0, \beta_{3} \neq 0, \beta_{4} \neq 0, \beta_{5} \neq 0\end{array}$ \\
\hline Form equation & $\begin{array}{c}Y_{t}=\beta_{0}+\beta_{1} * X_{1, t}+\beta_{2} * X_{2, t}+\beta_{3} * X_{3, t}+\beta_{4} * X_{4, t}+\beta_{5} * X_{5, t}+\varepsilon_{t} \\
\ln (y)=\beta_{0}+\beta_{1} * \ln \left(X_{1, t}\right)+\beta_{2} * \ln \left(X_{2, t}\right)+\beta_{3} * \ln \left(X_{3, t}\right)+\beta_{4} * \ln \left(X_{4, t}\right)+\beta_{5} * \ln \left(X_{5, t}\right)+\varepsilon_{t}\end{array}$ \\
\hline $\begin{array}{l}\text { Source of information } \\
\quad(\text { see the app 1) }\end{array}$ & $\begin{array}{c}\text { Unified statistical database of } / \mathrm{www} 1212 . \mathrm{mn} / \\
\text { Ministry of education and culture statistic information } \\
\text { Household social- economic research }\end{array}$ \\
\hline Period & 2001year-2019year. \\
\hline
\end{tabular}

Note: Hypothesis is determined; $5 \%$ significance level refutes the zero assumption that average monthly household income does not affect the change in the number of students in the higher education sector. In other words, the average monthly household income has a positive impact on the number of students. 


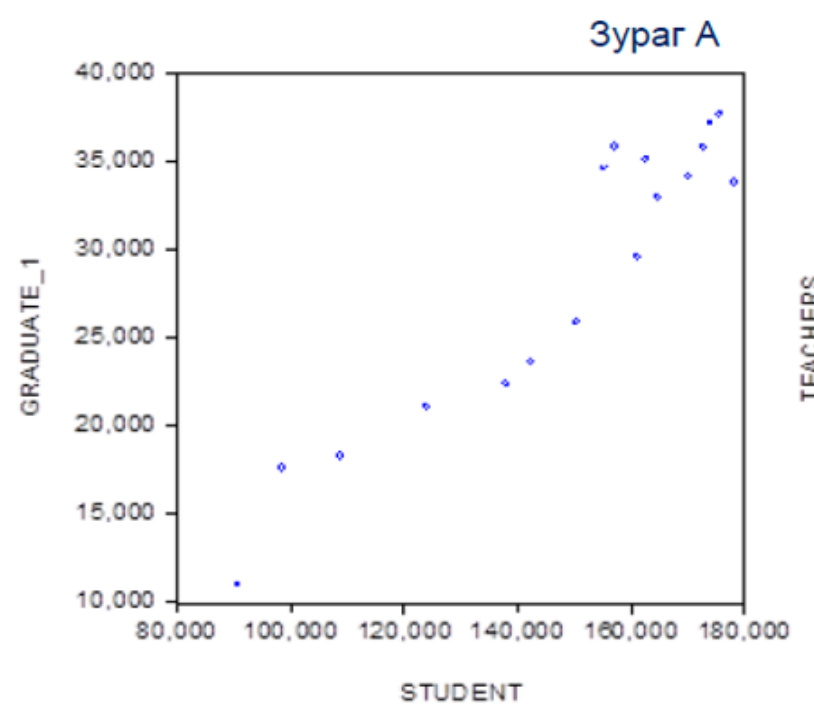

The number of students, which is a factor in the demand for higher education, depends on the number of graduates with completed secondary education. Another interesting aspect of these is:

- The demand for higher education is positively correlated with the proposal in the previous year, with a positive linear relationship between the number of students this year and the number of graduates in the previous year.

\section{/ Image A /}

- There is a positive linear relationship between the number of graduates in a given year and the number of full-time teachers in a given year. / Image B /

The following section shows the impact of changes in social, economic, and household indicators on changes in the number of students, a key indicator of higher education.

\subsection{Higher Education Reform, Development Policy, Tendency}

After the 1990s, democratic movement social and economic conditions changed, as a result, all circumstances to introduce market mechanisms to universities and institutes were created.

In 1991, Entity Law [6] was approved and Mongolian higher education was transformed into market principles. It became the fundament for the decentralizing of governance at all levels, creating the private sectors, transferring to tuition fees. According to this law since 1993, State universities and institutes introduced tuition fees.

According to Entity Law, which was approved in 1995, universities and institutes were given the opportunity to have diversified finances such as research, tuition fees, donation, loan, besides university's budgets. Also, multiple controls such as governance, human resource, contents of educational programs were decentralized as well as institution activity was expanded. During the period of

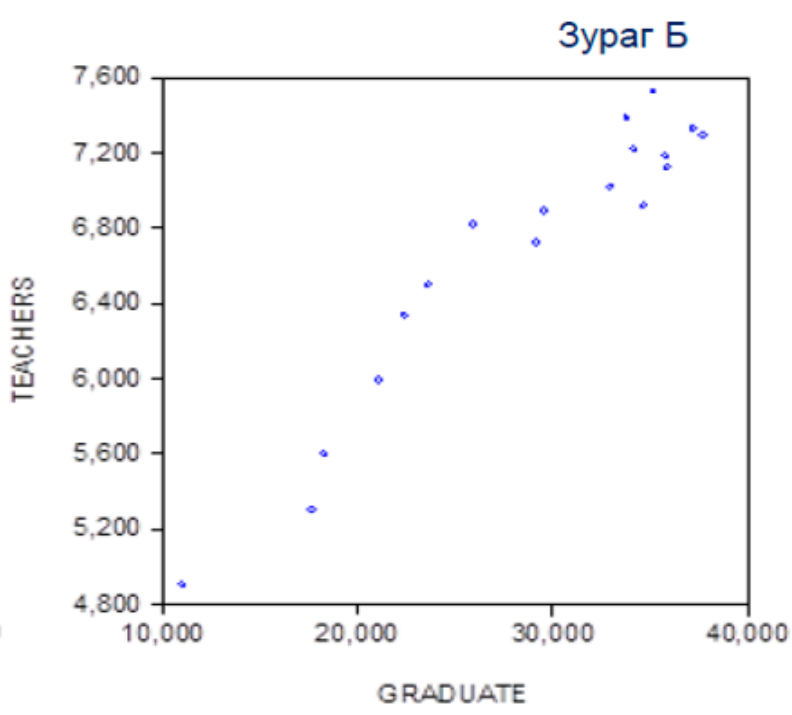

transition to market system, institutions and individuals faced sudden changes, consequently, requirements such as to change views, moral and behaviors arose. Similarly, higher educational institutions underwent cultural changes, so it was necessary to create a new system, a new training program, since that time the procedure of transforming higher education into a market system started.

Having determined the main directions of Mongolian Government's "Educational Master Plan", the transformation process and the policy of higher education into a market system was implemented.

In 2000, the "Law of Higher Education" was approved since that time the State's key policy was to improve the competitiveness of higher education institutions and bring it closer to international standards. In 2002, "Entity law" and "The law of higher education" were updated and approved. Since that time in 2006, 2008, 2012, 2015, 2016, 2017 in "Laws of higher education" were made amendments, within these laws Government's decree, regulations, action plans were approved. Since 2002, Mongolian Parliament, government have approved laws and policy documents about developing higher education branch in accordance with the law. For instance, "Master plan to develop education between 2006-2015" (2006), "Requirements for opening foreign universities, institutes, the branch of college, programs, joint programs" (2007), "The reform map of higher education" (2010-2021), "The certification procedure of higher education institutions"( The Ministry of education, culture and science, 2008), "Developing universities as campus" (2010), "The Classification procedure of higher education" (2010), "The law on financing of higher education institutions and social security of students" (2011), "National program for the development of results-based education" (2018), "Typical requirements for teachers of higher education institutions"(2020).

Mongolian development policy of higher education related to "Global sustainable development policy", "Education 2030-Incheon Declaration", "Vision 
2050-Mongolian long term development policy, "State policy on education" is striving to build a knowledge-based society, accelerate economic development, improve people's lives, create productive structure which assists to ensures social equality. With the frame of higher education reform in Mongolia, it is vital to create a qualified higher education structure with equal access. Also, to increase the number of graduates who are sensitive to labor market demand as well as competitive in the world.

\subsection{Current Situation of Higher Education Reform}

From the middle of the 1990s until today, there has been an increase in numbers in the higher universities, and private universities have been established in large numbers. By 2004, 183 state and private universities, institutes, foreign university institutes had been set up, the branches of state universities were established in the countryside, as a result, the number of graduates increased, fluctuating from 17671 to 22397 [7] between 2001 and 2004.

However, since 2004 the number of states and private universities, as well as foreign universities has decreased, in the 2020-2021 academic year there are 95 institutions left and 36.8 percent of which are universities, 52.6 percent are institutes, 7.4 are colleges and 3.2 percent are branches of foreign universities [8]. Compared to previous year, the number of universities, colleges, and branches of foreign universities has remained the same, the number of universities has increased by 2 percent. 14 (66.7\%) out of 21 state schools are universities, 7 (33.3\%) are institutes, $21(29.6 \%)$ out of 71 private schools are universities, 43 $(60.6 \%)$ are institutes, $7(9.9 \%)$ are colleges [9].

According to the graphic, it is clearly observed that the number of university students has decreased by 9887 , that of college students has decreased by 238 , the number of students of foreign university branches has decreased by 73 . On the other hand, the number of institute students has increased by 1019 .

91.9 percent or 136397 students study in Ulaanbaatar, 8.1 percent or 12049 students study in the countryside (including branch schools), compared to previous year, the number of students studying in capital city has fallen by 9627 , the number of students studying countryside has fallen by 448 .

In Mongolia, the level of participation in higher education is high, for instance, 23 percent of females, 17 percent of males got master degrees [10] in 2018.

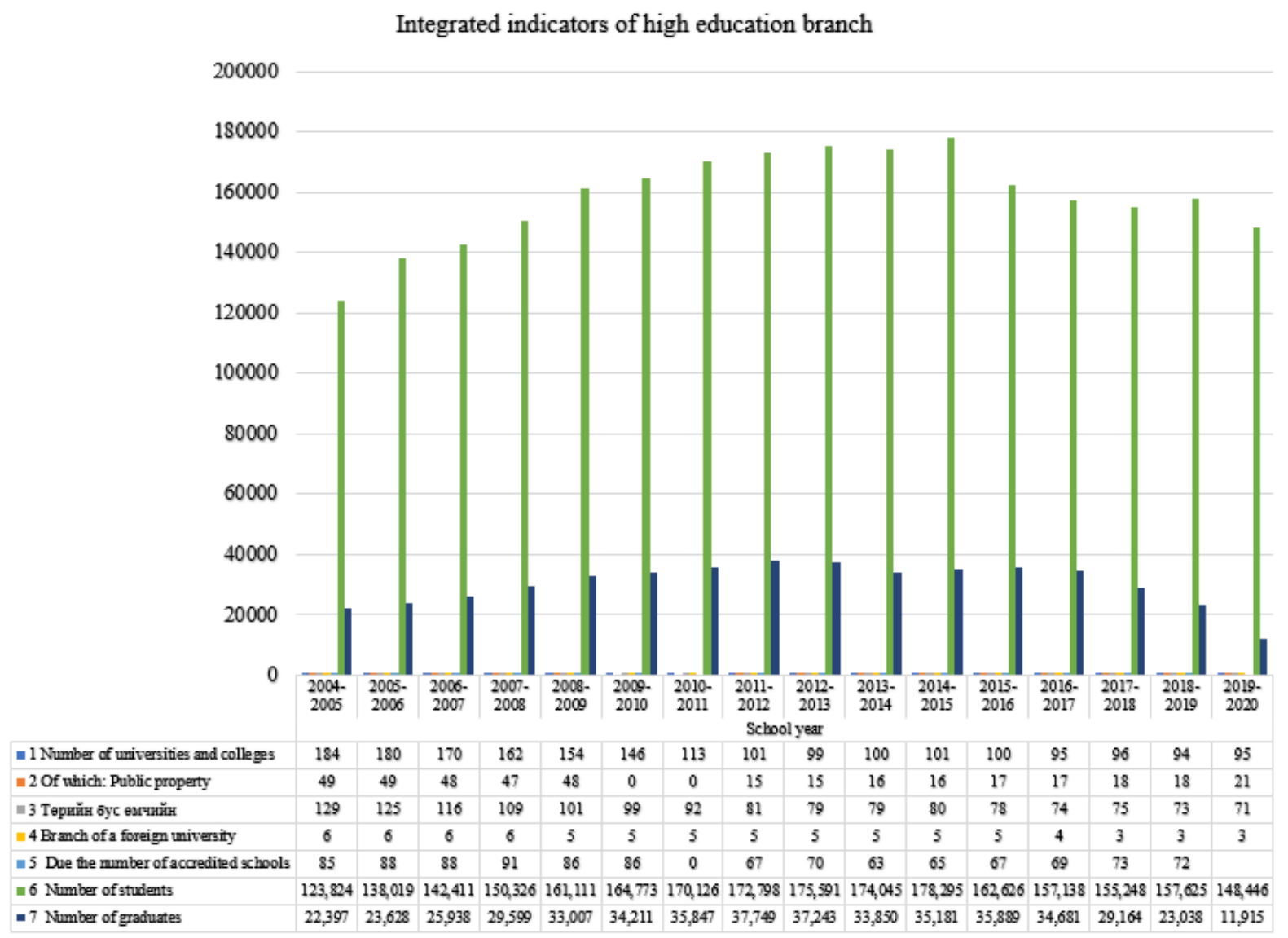

Graphic 1. Source: Mongolian Government, The Ministry of education, culture and science. https://www.meds.gov.mn/ 
We took at the impact of social and economic factors on the change in the number of students. The equation is assessed by students as a factor in the demand for higher education based on the results of the correction of the classical methodology of linear regression.

$$
\begin{array}{rl}
\ln \widehat{Y_{t}}=\beta_{0}+\beta_{1} & * \ln \left(\widehat{X_{1, t}}\right)+\beta_{2} * \ln \left(\widehat{X_{2, t}}\right)+\beta_{3} * \ln \left(\widehat{X_{3, t}}\right) \\
& +\beta_{4} * \ln \left(\widehat{X_{4, t}}\right)+\beta_{5} * \ln \left(\widehat{X_{5, t}}\right)+\varepsilon_{t} \\
\ln \widehat{Y_{t}}=3258200+0.2660 * \ln \left(\widehat{X_{1, t}}\right)-322.7652 \\
& * \ln \left(\widehat{X_{2, t}}\right)+0.0032 * \ln \left(\widehat{X_{3, t}}\right) \\
& -325.3556 * \ln \left(\widehat{X_{4, t}}\right)-5428.492 \\
& * \ln \left(\widehat{X_{5, t}}\right)
\end{array}
$$

The results of the estimate for 19 years show that if other factors are considered permanent or unchanged, the change in the total number of students is based on average monthly household income, positive GDP in constant valuable 2010, average tuition fees, as well as teachers and higher education schools. The negative impact of the numbers is shown by the above equations. (See appendix two for details about calculations). According to the revised estimates, if the average monthly household income increases by $1 \%$, the number of students receiving higher education in the current academic year will increase by $0.26 \%$. However, the $1 \%$ increase in GDP will have a positive impact on the total number of students this year, although it will not change significantly. In addition, the introduction of results-based education is likely to improve the quality of higher education and reduce the number of stately teachers and universities.

This means that there will be a small number of universities with creative teachers or human resources.

The higher education structure has changed a lot recently, prioritizing international standards. The reform of higher education has been implementing at sector level as well as at the level of higher education institutions. On the other hand, within the frame of complex policy, higher education programs should be transformed into business research institutions based on supply and demand, therefore, the participation of students, professors, scientists, business organizations, and the government in the decision making process is very essential.

The branch of higher education is expanding all over the world. The more the number of students, the more the number of unemployed graduates. Higher education institutions should provide education that meets labor market demand. As a consequence, it is necessary to renovate educational standards, teaching methods in order to develop essential skills which are vital to compete in the labor market. As higher education is closely related to graduates' employment, the training programs of higher education should be renovated.

\section{Results and Discussion: Higher Education Reform, Innovation Attitudes}

Both Mongolian government and labor market prioritize to develop internal quality assurance. Because internal quality assurance not only improves teaching methods but also increases the number of employed graduates. "Vision 2050-Mongolian long term development policy's goal [11] is to develop socially active, healthy Mongolians. Also, it is stated that everyone has the equal right to access to qualified education which is a guarantee of life quality, family life, fundament of the country's flourishment. The major target of this long term development policy is to create equal opportunity to access to qualified education, make education a guarantee of individual's development, strengthen life-long learning systems.

In order to achieve above mentioned goals, it is planned to do the following reform in higher education.

First phase: To create opportunities for everyone to access to qualified education during the reform of the system of equal coverage. To create a higher education system that prepares skilled, qualified graduates, meeting international labor markets demands.

Second phase (2031-2040): To increase the number of internationally-recognized higher education training institutions and establish an internationally-ranked national research university during the period of possessing qualified education and strengthening life-long learning systems.

Third phase (2041-2050): To enhance open training program contents and introduce technology based on artificial intelligence at all higher education levels during the period of supporting life-long learning systems.

The assessment of future aspects of students and graduates based on time data (2001-2019):

Transformed exponential trend model:

$$
\begin{aligned}
& \log \left(Y_{i}\right)=\log \left(\beta_{0} \beta_{1}^{x_{i}} \varepsilon_{i}\right) \\
= & \log \left(\beta_{0}\right)+\log \left(\beta_{1}^{x_{i}}\right)+\log \left(\varepsilon_{i}\right) \\
= & \log \left(\beta_{0}\right)+X_{i} \log \left(\beta_{1}\right)+\log \left(\varepsilon_{i}\right)
\end{aligned}
$$

Equation is a liner model I'm estimate using the least-squares method, with $\log \left(\mathrm{Y}_{\mathrm{i}}\right)$ as the dependent variable and $\mathrm{X}_{\mathrm{i}}$ as the independent variable. This result in equation:

Exponential trend forecasting equation:

$$
\log \left(\widehat{Y}_{l}\right)=b_{0}+b_{1} X_{i}
$$

Where

$$
\begin{aligned}
& b_{0}=\text { estimated of } \log \left(\beta_{0}\right) \text { and thus } 10^{b_{0}}=\widehat{\beta_{0}} \\
& b_{1}=\text { estimated of } \log \left(\beta_{1}\right) \text { and thus } 10^{b_{1}}=\widehat{\beta_{1}}
\end{aligned}
$$


therefore, $\widehat{Y_{l}}=\widehat{\beta_{0}} \widehat{\beta_{1}} \times i$

If the number of students is predicted by exponential dynamic analysis:

$$
\begin{gathered}
\log \left(\widehat{Y}_{l}\right)=5.1617+0.0005 X_{i} \\
b_{0}=\text { estimated of } \log \left(\beta_{0}\right) \text { and thus } 10^{5.1617} \\
=145110.9 \\
b_{1}=\text { estimated of } \log \left(\beta_{1}\right) \text { and thus } 10^{0.0005} \\
=1.00115
\end{gathered}
$$

Forms of exponential trend hypothesis equations:

$$
\begin{gathered}
\widehat{Y_{l}}=145110.91 .00115^{X i} \\
\log \left(\widehat{Y_{20}}\right)=5.1617+0.0005 * 20=148491.0 \\
\log \left(\widehat{Y_{21}}\right)=5.1617+0.0005 * 21=148662.0
\end{gathered}
$$

(See Appendix one or three for the calculation results process)

According to the graphic, the number of graduates from $2020-2022$ is predicted to remain the same as the previous years. On the other hand, from 2023 to 2029 the figure is anticipated to increase, with the number of students fluctuating between 148491.0 and 150210.4. Besides learning labor skills, higher education training institutions have played a main role in creating and spreading economical, ecological, social and cultural development knowledge [12]. In the question of reform of Mongolian higher education, the following issues are faced:

- Making quality assurance to higher education degrees, creating credit hours transforming systems. Developing an open training program including e-learning that meets quality standards, financing distance learning.

- Improving the productivity of institutes and universities research work.

- Strengthening foreign cooperation in order to create scientific research programs and creating conditions to consent mutually professional as well as scientific degrees.
- Giving equal opportunity to access to education without discrimination, regardless of social-cultural backgrounds, social status, gender.

- The aim of higher education training institutions is to provide students with life-long learning education.

\section{Conclusions}

Due to the fact that change goes from top to bottom and innovation from top to bottom and from bottom to top, qualitative change is more appropriate to call innovation in higher education.

The consultants of "Higher Education Reform projects" mentioned in their reports [10] that "Mongolia is one the historically development counties with a good foundation of higher education". Higher education reform has played a main role in preparing international-competitive Mongolians, developing knowledge-based economy, and introducing the outcomes of the "Fourth Industrial Revolution" into service sectors.

By 1st of July, 2020, there have been 76 accredited higher education training institutions, 1 branch of foreign institute, 110 internationally accredited training programs [13]. Higher education training institutions play a key role in education and attitudes of future leaders and scientists.

Due to high demand in high qualified specialists, it is vital to create policy to develop and classify universities as well as institutes, create national and rural development models. Basing on international and Mongolian best experience of e-learning and distance-learning, it is necessary to do research to introduce open education and open-source of education to higher education institutions, taking into account the specific circumstances of Mongolia.

As the result of this research, it is essential to use open-source of education as a long-life learning additional program, support cooperation of scientists at both national and domestic levels, improve the quality of higher education training institutions. 
Table 2. Forecast of the number of students as a factor in the demand for higher education

\begin{tabular}{|c|c|c|c|c|c|c|c|c|c|c|c|}
\hline & 2020 & 2021 & 2022 & 2023 & 2024 & 2025 & 2026 & 2027 & 2028 & 2029 & 2030 \\
\hline $\begin{array}{l}\text { D-demand- } \\
\text { students }\end{array}$ & 148491.0 & 148662.0 & 148833.3 & 149004.7 & 149176.4 & 149348.2 & 149520.2 & 149692.5 & 149865.0 & 150037.6 & 150210.4 \\
\hline $\begin{array}{l}\text { S- supply- } \\
\text { graduates }\end{array}$ & 23009.0 & 25756.7 & 28455.6 & 30395.5 & 32027.3 & 33373.5 & 31873.2 & 31803.3 & 31056.2 & 30145.1 & 29007.3 \\
\hline
\end{tabular}

Source: Researcher's estimation.

\section{Appendix 1. Basic Indicators of Higher Education}

\begin{tabular}{|c|c|c|c|c|c|c|c|}
\hline Year & $\begin{array}{c}\text { Number of students in } \\
\text { higher education } \\
\text { institutions }\end{array}$ & $\begin{array}{l}\text { Number of } \\
\text { graduates }\end{array}$ & $\begin{array}{c}\text { Average monthly } \\
\text { household income, } \\
\text { MNT }\end{array}$ & $\begin{array}{l}\text { Average tuition fee, } \\
\text { thousand MNT }\end{array}$ & $\begin{array}{l}\text { GDP / at } 2010 \\
\text { constant prices / }\end{array}$ & $\begin{array}{l}\text { Number of basic teachers } \\
\text { in higher education }\end{array}$ & $\begin{array}{c}\text { Number of universities and } \\
\text { colleges }\end{array}$ \\
\hline 2001 & 906644 & 17671 & 102133 & 217.9 & 5360870.5 & 5346 & 178 \\
\hline 2002 & 98453 & 18289 & 124930 & 251.4 & 5614599.3 & 5642 & 185 \\
\hline 2003 & 108738 & 21109 & 144354 & 258.1 & 6007881.5 & 5990 & 183 \\
\hline 2004 & 123824 & 22397 & 144127 & 297.8 & 6646243.3 & 6337 & 184 \\
\hline 2005 & 138019 & 23628 & 150208 & 343.5 & 7128339.5 & 6517 & 180 \\
\hline 2006 & 142411 & 35938 & 173477 & 396.3 & 7738257 & 6818 & 170 \\
\hline 2007 & 15326 & 29599 & 239179 & 457.2 & 8531274.9 & 6892 & 162 \\
\hline 2008 & 161111 & 33007 & 325270 & 527.5 & 9290589.7 & 7020 & 154 \\
\hline 2009 & 164773 & 34211 & 354967 & 608.6 & 9172729.4 & 7219 & 146 \\
\hline 2010 & 170126 & 35847 & 387099 & 723.5 & 9756588.4 & 7183 & 113 \\
\hline 2011 & 172758 & 37749 & 503936 & 859.3 & 11443578 & 7295 & 101 \\
\hline 2012 & 175591 & 17243 & 741917 & 1007.6 & 12853407 & 7331 & 99 \\
\hline 2013 & 174075 & 33850 & 882511 & 1221.1 & 14350689 & 7385 & 100 \\
\hline 2014 & 178295 & 35181 & 974392 & 1542.1 & 15482273 & 7528 & 101 \\
\hline 2015 & 162626 & 35889 & 945118 & 1765.2 & 15850726 & 7121 & 100 \\
\hline 2016 & 157138 & 34681 & 883259 & 1932.6 & 16035925 & 6917 & 95 \\
\hline 2017 & 155248 & 29164 & 936187 & 2124.7 & 16886097 & 6724 & 96 \\
\hline 2018 & 157625 & 23000 & 1062372 & 2233.3 & 18059484 & 6668 & 94 \\
\hline 2019 & 148446 & 28045 & 1230300 & 2200.5 & 5314553.8 & 6870 & 95 \\
\hline
\end{tabular}

source: Ministry of education and culture statistic information, www.1212.mn 


\section{Appendix 2. Multivariate Linear Regression Model Calculation}

(The impact of social and economic factors on changes in the number of students)

\begin{tabular}{|c|c|c|c|c|}
\hline Dependent Variable: SER01- Yt & & & & \\
\hline \multicolumn{5}{|c|}{ Method: Least Squares (Gauss-Newton / Marquardt steps) } \\
\hline \multicolumn{5}{|l|}{ Date: $11 / 19 / 20$ Time: $23: 36$} \\
\hline \multicolumn{5}{|l|}{ Sample: 20012019} \\
\hline \multicolumn{5}{|l|}{ Included observations: 19} \\
\hline \multicolumn{5}{|c|}{$\mathrm{Yt}=\mathrm{C}(1)+\mathrm{C}(2) * \mathrm{SER} 04+\mathrm{C}(3) * \mathrm{SER} 05+\mathrm{C}(4) * \mathrm{SER} 06+\mathrm{C}(5) * \mathrm{SER} 07+\mathrm{C}(6) * \mathrm{SER} 08$} \\
\hline & Coefficient & Std. Error & t-Statistic & Prob. \\
\hline $\mathrm{C}((1)$ & 3258200 & 1078340 & 3.021494 & 0.0098 \\
\hline $\mathrm{C}(2)$ & 0.266047 & 0.477188 & 0.55753 & 0.5866 \\
\hline $\mathrm{C}(3)$ & -322.7652 & 228.1148 & -1.414925 & 0.1806 \\
\hline $\mathrm{C}(4)$ & 0.003245 & 0.014959 & 0.21691 & 0.8316 \\
\hline $\mathrm{C}(5)$ & -325.3556 & 105.6339 & -3.08003 & 0.0088 \\
\hline$C(6)$ & -5428.492 & 3167.725 & -1.713688 & 0.1103 \\
\hline R-squared & 0.445443 & $\begin{array}{c}\text { Mean } \\
\text { dependent } \\
\text { var }\end{array}$ & & 184801.4 \\
\hline Adjusted R-squared & 0.232151 & $\begin{array}{l}\text { S.D. } \\
\text { dependent } \\
\text { var }\end{array}$ & & 178959.9 \\
\hline S.E. of regression & 156817.2 & $\begin{array}{l}\text { Akaike info } \\
\text { criterion }\end{array}$ & & 27.01564 \\
\hline Sum squared reside & $3.20 \mathrm{E}+11$ & $\begin{array}{l}\text { Schwarz } \\
\text { criterion }\end{array}$ & & 27.31388 \\
\hline Log likelihood & -250.6486 & $\begin{array}{c}\text { Hannan- } \\
\text { Quinn } \\
\text { criterion }\end{array}$ & & 27.06611 \\
\hline F-statistic & 2.088423 & $\begin{array}{c}\text { Durbin- } \\
\text { Watson stat }\end{array}$ & & 1.835567 \\
\hline Prob(F-statistic) & 0.132158 & & & \\
\hline
\end{tabular}

Source: Researcher's estimation. Calculated by Eviews9.0.
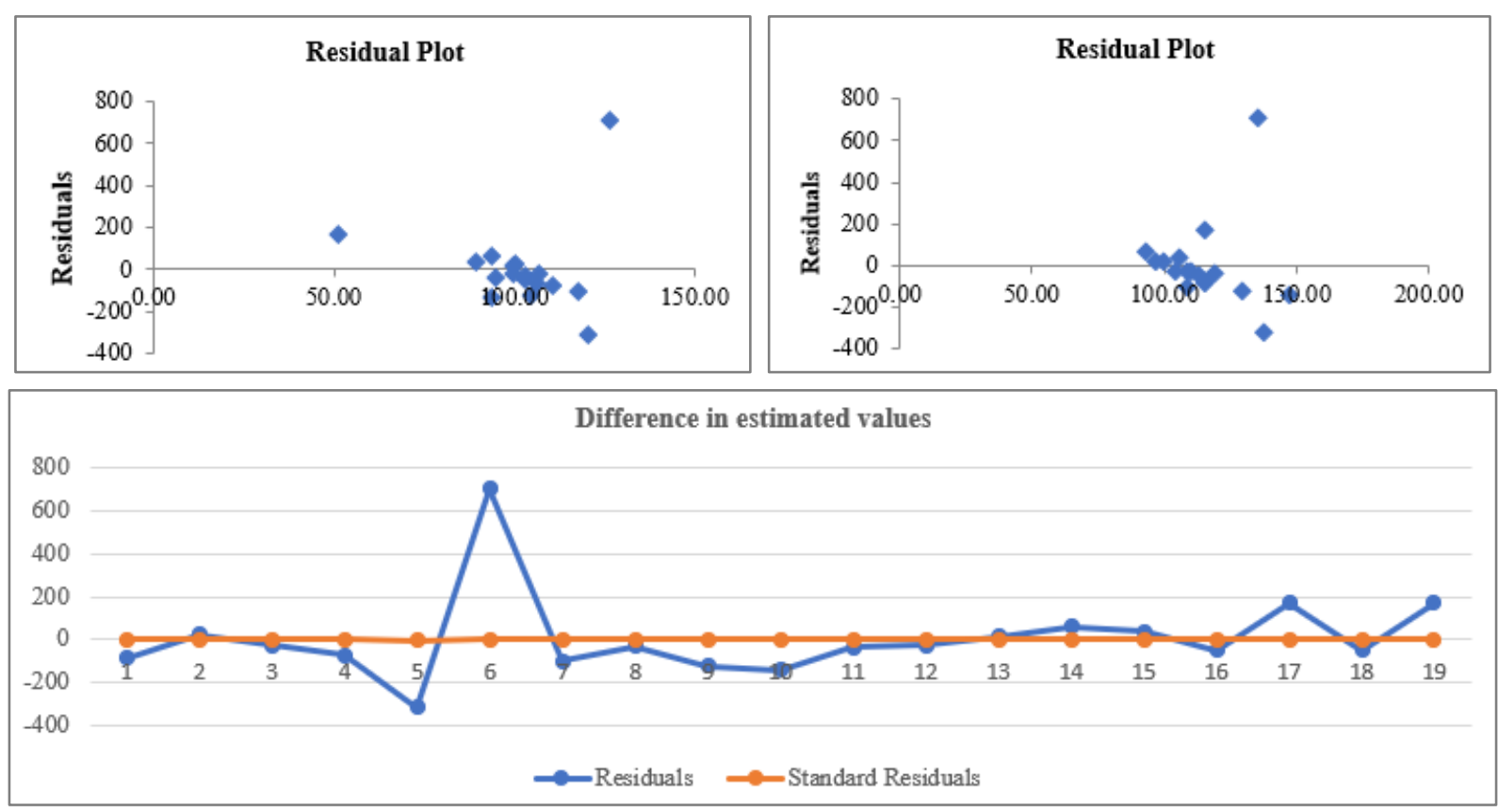

Graphics. A graph of the results of the corrected value 


\section{Appendix 3. Predicting the Number of Students by Exponential Dynamic Analysis}

\begin{tabular}{|c|c|c|c|c|c|c|c|c|}
\hline $\begin{array}{c}\text { SUMMARY } \\
\text { OUTPUT }\end{array}$ & & & & & & & & \\
\hline \multicolumn{9}{|l|}{$\begin{array}{c}\text { Regression } \\
\text { Statistics }\end{array}$} \\
\hline Multiple R & 0.00884668 & & & & & & & \\
\hline R Square & 7.8264E-05 & & & & & & & \\
\hline $\begin{array}{c}\text { Adjusted R } \\
\text { Square }\end{array}$ & -0.05874066 & & & & & & & \\
\hline $\begin{array}{c}\text { Standard } \\
\text { Error }\end{array}$ & 0.31415583 & & & & & & & \\
\hline Observations & 19 & & & & & & & \\
\hline \multicolumn{9}{|l|}{ ANOVA } \\
\hline & $d f$ & $S S$ & $M S$ & $F$ & Significance F & & & \\
\hline Regression & 1 & 0.000131321 & 0.0001313 & 0.0013306 & 0.971326751 & & & \\
\hline Residual & 17 & 1.677796042 & 0.0986939 & & & & & \\
\hline \multirow[t]{2}{*}{ Total } & 18 & 1.677927363 & & & & & & \\
\hline & Coefficients & Standard Error & $t$ Stat & $P$-value & Lower 95\% & Upper $95 \%$ & Lower $95.0 \%$ & $\begin{array}{l}\text { Upper } \\
95.0 \%\end{array}$ \\
\hline Intercept & 5.16173548 & 0.138633818 & 37.232874 & $9.79 \mathrm{E}-18$ & 4.86924369 & 5.454227268 & 4.86924369 & 5.454227268 \\
\hline $\mathrm{X}$ Variable 1 & 0.00047999 & 0.01315854 & 0.0364772 & 0.9713268 & -0.027282105 & 0.028242079 & -0.027282105 & 0.028242079 \\
\hline
\end{tabular}

Source: Researcher's estimation. Calculated by Data Analysis

[6] Law on Education of Mongolia, 1991.

\section{REFERENCES}

[1] UN, Universal Declaration of Human Rights". https://www.un.org/en/universal-declaration-human-rights/ 26.1. 1948.

[2] UNESCO, Recommendation concerning the Status of Higher-Education Teaching Personnel (1997).1.1. Held from October 21, 1997 to November 12, 1997 and approved by the 29th General Conference of UNESCO, Paris. 1997. http://portal.unesco.org/en/ev.php-URL_ID=13144\&URL_ DO=DO_TOPIC\&URL_SECTION $=20 \overline{1} . \mathrm{html}$

[3] National University of Mongolia, National University of Mongolia figures. $2020 / / \mathrm{https}$ //www.num.edu.mn.

[4] UNESCO, Recommendation concerning the Status of Higher-Education Teaching Personnel 1.5, 1997. https://www.ilo.org/wcmsp5/groups/public/---ed_dialogue/--sector/documents/normativeinstrument/wcms_493315.pdf

[5] Parliament of Mongolia. "The government policy on education".2014-2024. Annex to the 12th resolution of the Parliament of Mongolia in 2015, https://www.legalinfo.mn/ annex/details/6661 ?lawid $=10935$

[7] Mongolian statistical information service. Higher education. 2020. https://www.1212.mn/default.aspx.

[8] https://www.1212.mn/default.aspx.

[9] MEDS. Institute of education. "Overview of educational development", Mongolian National Education Policy Review Analysis, Ulaanbaatar. 2019. pp46-48.

[10] Parliament of Mongolia "Vision 2050-Mongolia's long-term development policy". Objective 2. Annex 1 to the Resolution No. 52 of the Parliament of Mongolia of 2020. https://www.legalinfo.mn/law/details/15406

[11] UNESCO Institute for Information Technologies in Educatio "Education-2030". Incheon Declaration. 2015. https://iite.unesco.org/publications/education-2030-incheon -declaration-framework-action-towards-inclusive-equitablequality-education-lifelong-learning/

[12] Asian Development Bank. Higher Education Reform Project" consultants' work report, 2019. https://www.adb.org/project s/documents/higher-education-reform-project-mongolia-rrp

[13] Mongolian National council for education accreditation. Accreditation. 2020. http://accmon.mn/ 